\title{
EVALUASI KERENTANAN GEDUNG REKTORAT STTNAS TERHADAP GEMPA BUMI BERDASARKAN ANALISIS MIKROTREMOR
}

\author{
Rizqi Prastowo ${ }^{1}$, Urip Nurwijayanto Prabowo ${ }^{2}$ \\ Jurusan Teknik Pertambangan ${ }^{1}$, Jurusan Pendidikan Fisika FMIPA ${ }^{2}$ \\ Sekolah Tinggi Teknologi Nasional ${ }^{1}$, Universitas Sarjanawiyata Tamansiswa ${ }^{2}$ \\ J1. Babarsari ${ }^{1}$, Jl. Batikan ${ }^{2}$ \\ rizqi@sttnas.ac.id
}

\begin{abstract}
STTNAS building is a five floor building that located in the city of Yogyakarta which is an area with a high intensity earthquake occurrence. The purpose of this study is (1) determine the value of the natural frequencies of the building, (2) determine the index of the resonance of the building and (3) the vulnerability of buildings to earthquakes.

Research will be done by measuring the microtremor wave of building STTNAS then analyzed using Spectral Floor Ratio (FSR). The analysis result is then compared with the classification defined in ISO 2002 on building resilience planning procedures earthquake.

Fekuensi natural on the east-west component is $1.64 \mathrm{~Hz}$ and the north-south component is $1.644 \mathrm{~Hz}$ that is in conformity with the ISO 2002. Resonance Index of building STTNAS is ranging from 31.00081 to $35.883 \%$ thus including the low category resonance during an earthquake. Building of STTNAS vulnerability index ranges are between 103,670.6191 to 82526.5357 with the highest value found on the 4th floor.
\end{abstract}

\begin{abstract}
ABSTRAK
Gedung rektorat STTNAS merupakan gedung berlantai 5 yang terletak di Kota Yogyakarta yang merupakan daerah dengan intensitas kejadian gempabumi yang tinggi. Tujuan penelitian ini adalah (1) menentukan nilai frekuensi natural bangunan, (2) menentukan indeks resonansi bangunan dan (3) tingkat kerentanan bangunan terhadap gempabumi.

Penelitian akan dilakukan dengan melakukan pengukuran gelombang mikrotremor dari bangunan gedung rektorat STTNAS kemudian dianalisis menggunakan metode Floor Spectral Ratio (FSR). Hasil analisis kemudian dibandingkan dengan klasifikasi yang ditetapkan pada SNI 2002 tentang tata cara perencanaan ketahanan bangunan gempa.

Fekuensi natural pada komponen barat-timur adalah 1,64 Hz dan pada komponen utara-selatan adalah $1,644 \mathrm{~Hz}$ sehingga sudah sesuai dengan SNI 2002. Indeks Resonansi gedung rektorat STTNAS berkisar antara 31,00081-35,883\% sehingga temasuk dalam kategori rendah mengalami resonansi saat terjadi gempabumi. Indeks kerentanan gedung rektorat STTNAS berkisar antara 103670,619182526,5357 dengan nilai tertinggi terdapat pada lantai 4 .
\end{abstract}

Keyword: Mikrotremor, FSR, Kerentanan Bangunan

\section{Pengantar/Introduction}

Daerah Istimewa Yogyakarta (DIY) merupakan salah satu daerah rawan bencana gempabumi, hal tersebut dikaarenakan letaknya berdekatan dengan daerah pertemuan antara lempeng Eurasia dan lempeng Hindia Australia (Broptopuspito, dkk., 2006). Pada tanggal 27 
Mei 2006 dengan gempabumi dengan magnitudo 6,2 Mw, merusak bangunan maupun mengakibatkan korban jiwa, dengan 5700 korban meninggal, 37.000 korban luka dan lebih dari 156.00 rumah dan bangunan mengalami kerusakan (Elnashai, dkk., 2006).

Sekolah Tinggi Teknologi Nasional (STTNAS) merupakan sekolah tinggi yang terletak di Kabupaten Sleman, D.I. Yogyakarta yang merupakan daerah rawan gempabumi, sehingga pembuatan bangunan/ gedung perkuliahan maupun perkantoran di lingkup STTNAS harus memenuhi standar bangunan tahan gempa sesuai dengan SNI 2002 tentang tata cara perencanaan ketahanan bangunan gempa.

Bangunan yang aman dan tahan gempabumi adalah bangunan yang memenuhi SNI 2002 tentang tata cara perencanaan ketahanan bangunan gempa. Selain itu bangunan juga memiliki frekuensi natural yang lebih besar daripada frekuensi natural tanah, nilai indeks resonansi dan nilai kerentanan bangunan yang kecil (Gosar, dkk., 2010).

\subsection{Respon Bangunan Terhadap Gempabumi}

Menurut Coburn dan Spence (2002), yang menjadi penyebab utama kerusakan bangunan saat terjadi gempabumi adalah getaran pada tanah dasar bangunan. Getaran pada tanah ini akan menyebabkan gaya inersia yang bekerja pada bangunan sehingga meningkatkan percepatan getaran bangunan. Jika bangunan kaku sempurna maka energi inersia akan menyebar merata ke seluruh bagian bangunan, namun pada umumnya bangunan tidak benar-benar kaku sempurna.

Respon bangunan atas adanya getaran pada dasar tanah sangat bergantung pada frekuensi alami bangunan (natural frequency) yang merupakan jumlah getaran yang terjadi pada bangunan tiap detik. Nilai frekuensi alami/natural bangunan berbeda beda dan sangat bergantung pada tinggi bangunan dimana bangunan tinggi akan bergetar lebih lambat dibandingkan bangunan yang rendah. Jika frekuensi getaran tanah dasar bangunan lebih kecil daripada frekuensi natural bangunan maka bangunan dinyatakan aman dari kerusakan akibat deformasi. Peningkatan frekuensi getaran tanah akan meningkatkan deformasi bangunan dan jika frekuensi getaran tanah sama dengan frekuensi natural bangunan maka akan terjadi efek resonansi dan deformasi akan mencapai puncaknya. Efek resonansi merupakan efek penguatan amplitudo gelombang dimana jika terdapat gaya paksa (gempabumi) dengan frekuensi yang mendekati frekuensi alami sistem (bangunan) maka sistem akan berosilasi dengan amplitudo yang jauh lebih besar daripada amplitudo gaya paksa (Tipler, 1991).

Bangunan yang aman dan tahan gempabumi adalah bangunan yang memenuhi SNI 2002 tentang tata cara perencanaan ketahanan bangunan gempa. Menurut standar tersebut, nilai waktu getar alami fundamental $T l$ dari struktur gedung/bangunan dibatasi berdasarkan pada koefisien $\zeta$ dan jumlah tingkat bangunan $(n)$ menurut persamaan berikut:

$$
T<n \zeta
$$

di mana koefisien $\zeta$ ditunjukkan pada tabel 1 dengan zona gempa D.I.Yogyakarta adalah zona 3 . 
Tabel 1. Nilai periode alami fundamental (T) bangunan (SNI, 2002)

\begin{tabular}{|c|c|}
\hline Wilayah & $\boldsymbol{\zeta}$ \\
\hline 1 & 0,20 \\
\hline 2 & 0,19 \\
\hline 3 & 0,18 \\
\hline 4 & 0,17 \\
\hline 5 & 0,16 \\
\hline 6 & 0,15 \\
\hline
\end{tabular}

\subsection{Floor Spectral Ratio (FSR)}

Metode Floor Spectral Ratio (FSR) merupakan metode yang dikemukakan oleh Gosar, dkk (2010) untuk menentukan frekuensi natural dan resonansi bangunan yang menggambarkan karakteristik bangunan terhadap gempabumi. Metode ini dilakukan dengan mengubah data rekaman mikrotremor dalam kawasan waktu menjadi data dalam kawasan frekuensi (spektrum) pada tiap komponen pengukuran mikrotremor (utara-selatan/NS dan timur-barat/EW). Selanjutnya dari spektrum tiap komponen dapat diketahui frekuensi natural bangunan yang merupakan frekuensi yang dapat menyebabkan bangunan beresonansi.

Terdapat beberapa metode lain dalam pengolahan data mikrotremor untuk memperoleh karakteristik bangunan. Namun metode FSR memiliki beberapa keunggulan antara lain metode FSR merupakan metode yang lebih akurat dalam penentuan resonansi tanah dibandingkan Random Decrement Method (RDM) (Aini, dkk., 2012). Selain itu penggunaan metode HVSR dalam analisis spektrum mikrotremor bangunan tidak dianjurkan karena belum ada teori yang valid dalam aplikasi metode HVSR untuk penentuan frekuensi natural bangunan dan tidak akurat jika amplifikasi tanah sangat besar karena kurva HVSR pengukuran di tanah pada luar bangunan bisa dipengaruhi oleh respon dari bangunan (Herak, 2011).

Pada metode FSR, karakteristik bangunan lain yang bisa didapatkan selain frekuensi natural adalah indeks resonansi bangunan dan indeks kerentanan bangunan. Indeks resonansi bangunan $(R)$ ditentukan berdasarkan spektrum tiap komponen (NS dan EW) yang dihitung berdasarkan persamaan berikut:

$$
R=\left|\frac{f_{b}-f_{t}}{f_{t}}\right| \times 100 \%
$$

dengan, $f_{b}$ adalah frekuensi natural bangunan, $f_{t}$ adalah frekuensi tanah.

Nilai indeks resonansi yang didapatkan kemudian digunakan untuk menentukan tingkat kemungkinan bangunan mengalami resonansi saat terjadi gempa berdasarkan klasifikasi dari Gosar, dkk (2010). Klasifikasi tersebut adalah sebagai berikut: (1) Resonansi bangunan rendah $(R>25 \%)$, (2) Resonansi bangunan sedang $(15 \%<R<25 \%$ ), (3) Resonansi bangunan tinggi $(R<15 \%)$.

Nilai indeks kerentanan bangunan $\left(\bar{K}_{b}\right)$ ditentukan berdasarkan persamaan yang dikemukakan oleh Nakamura, dkk (2009 dalam Sungkono, dkk., 2011) sebagai berikut:

$$
\bar{K}_{b}=\frac{A}{(2 \pi f)^{2}} \frac{10000}{H}
$$


dengan $A$ adalah amplifikasi dari analisis FSR, $f$ adalah frekuensi natural bangunan dari analisis FSR dan $H$ adalah ketinggian bangunan. Sedangkan untuk analisis FFT menggunakan persamaan berikut:

$$
X(f)=\frac{1}{T} \int_{-\infty}^{\infty} x(t) e^{-j 2 \pi f t} d t
$$

\section{Latar Belakang Masalah}

Kajian mengenai kondisi kerentanan bangunan Rektorat yang mencakup ruang yayasan, ruang dosen semua jurusan dan ruang administratif, sehingga kajian mengenai kerentanan bangunan sangat penting. Kajian kerentanan bangunan saat terjadi gempabumi merupakan sebuah langkah dalam perencanaan mitigasi gempabumi. Bangunan Rektorat memiliki 5 lantai. Lantai ke-1 merupakan auditorium. Lantai ke-2 merupakan bagian tata administrasi, bagian keuangan, bagian umum, akademik, dan sumber daya manusia. Lantai ke-3 merupakan ruang pengelola yayasan. Lantai ke-4 merupakan ruang jurusan dan ruang dosen. Lantai ke-5 merupakan ruang staf informatika, lapangan badminton dan staf marketing. terdiri atas satu ruang kuliah, ruang tata usaha, ruang dosen di lantai 1 dan ruang kuliah di lantai 2 .

Nilai frekuensi natural, indeks resonansi dan indeks kerentanan bangunan dapat diketahui berdasarkan pengukuran mikrotremor. Mikrotremor biasa disebut juga sebagai ambient noise yang merupakan getaran konstan yang kecil pada tanah dan lantai yang diakibatkan oleh angin kencang, pasang surut air laut, efek angin pada bangunan atau pohon, mesin industri, mobil, aktivitas manusia, gelombang laut dan lain sebagainya (Sungkono, dkk., 2011). Pengukuran mikrotremor memiliki banyak keunggulan dibanding pengukuran lain yaitu sangat efektif, cepat, reliabel, akurat dan memberikan hasil pengukuran yang stabil dalam menentukan fungsi transfer (frekuensi, resonansi dan indeks kerentanan bangunan (Sungkono, dkk., 2011) serta mampu menentukan karakteristik kondisi geologi lokal (frekuensi dan amplifikasi tanah) (Prabowo, dkk., 2016).

Hasil pengukuran mikrotremor selanjutnya dianalisis menggunakan metode Floor Spectral Ratio (FSR) yang dikemukakan oleh (Gosar, dkk., 2010). Metode ini dapat dengan efektif, mudah dan reliabel dalam menentukan nilai frekuensi natural, indeks resonansi dan indeks kerentanan bangunan seperti pada penelitian yang telah dilakukan oleh Sungkono, dkk (2011), Aini, dkk (2012), Prakosa, dkk (2014), dan Bahri, dkk (2016).

Berdasarkan uraian tersebut, maka diperlukan suatu kajian penelitian untuk mengetahui tingkat kerentanan bangunan Rektorat STTNAS sebagai masukan dalam upaya mitigasi bencana gempabumi.

\section{Metodologi Penelitian}

\subsection{Metode Pengambilan Data}

Data penelitian merupakan data primer yang diambil dari pengukuran mikrotremor di dalam gedung Rektorat STTNas dan di luar bangunan (open ground). Pengambilan data dilakukan dalam kondisi sepi agar di dapatkan frekuensi natural bangunan yang tidak dipengaruhi noise aktivitas di dalam bangunan. Bahan dan alat yang digunakan dalam penelitian ini antara lain Portable Digital Seismograph TDL 303S milik BMKG Yogyakarta, laptop untuk pengolahan data dan perangkat lunak berupa Microsoft Office 2013 dan Geopsy. 


\subsection{Metode Analisis Data}

Pengolahan data berdasarkan metode FSR, akan dilakukan dengan menggunakan software Geopsy. Rekaman data mikrotremor komponen utara-selatan (NS) dan timur-barat (EW) digunakan untuk menentukan frekuensi natural dari bangunan. Pengolahan dalam software geopsy meliputi windowing (pemotongan sinyal) data pengukuran mikrotremor dengan parameter tapering 5\%, merubah data tiap window kawasan waktu menjadi data dalam kawasan frekuensi (spektrum) melalui proses Fast Fourier Transform (FFT) kemudian dilakukan smooting (Konno \& Ohmachi, 1998) pada spektrum. Selanjutnya dihitung spektrum rata-rata dari spektrum seluruh window untuk menentukan nilai frekuensi natural bangunan. Indeks resonansi bangunan dihitung berdasarkan persamaan (1) dan indeks kerentanan bangunan dihitung berdasarkan persamaan (2).

\section{Hasil dan Pembahasan}

Hasil pada penelitian ini adalah berupa bentuk sinyal pada kawasan frekuensi mikrotermor dengan menggunakan FFT (Fast Fourier Tranasform). Melalui sinyal pada kawasan frekuensi tersebut dianalisis berupa frekuensi natural/ frekuensi dominan dan amplifikasi/ amplitudo. Bentuk-bentuk sinyal mikrotremor dapat dilihat pada gambar berikut
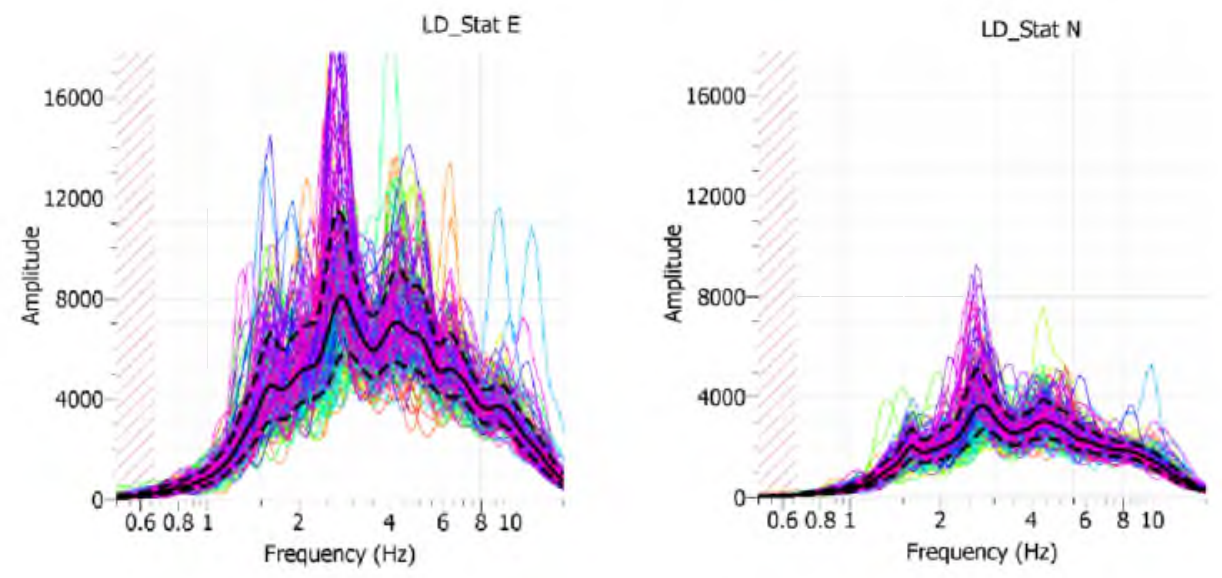

Gambar 1. Hasil FFT Mikrotremor pada Tanah (Ground)
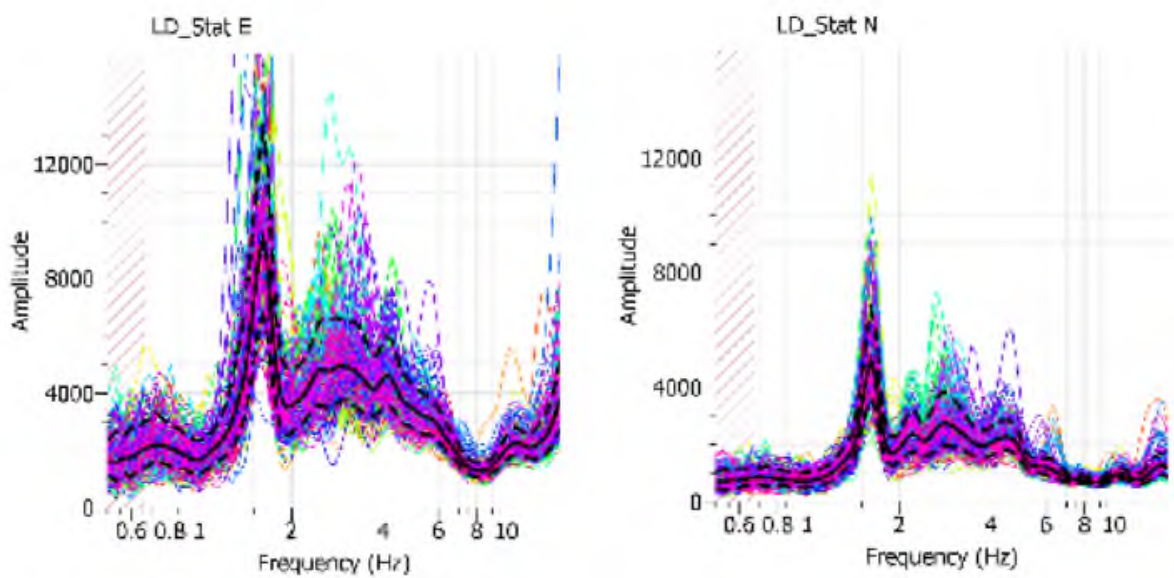

Gambar 2. Hasil FFT Mikrotremor pada Lantai 1 

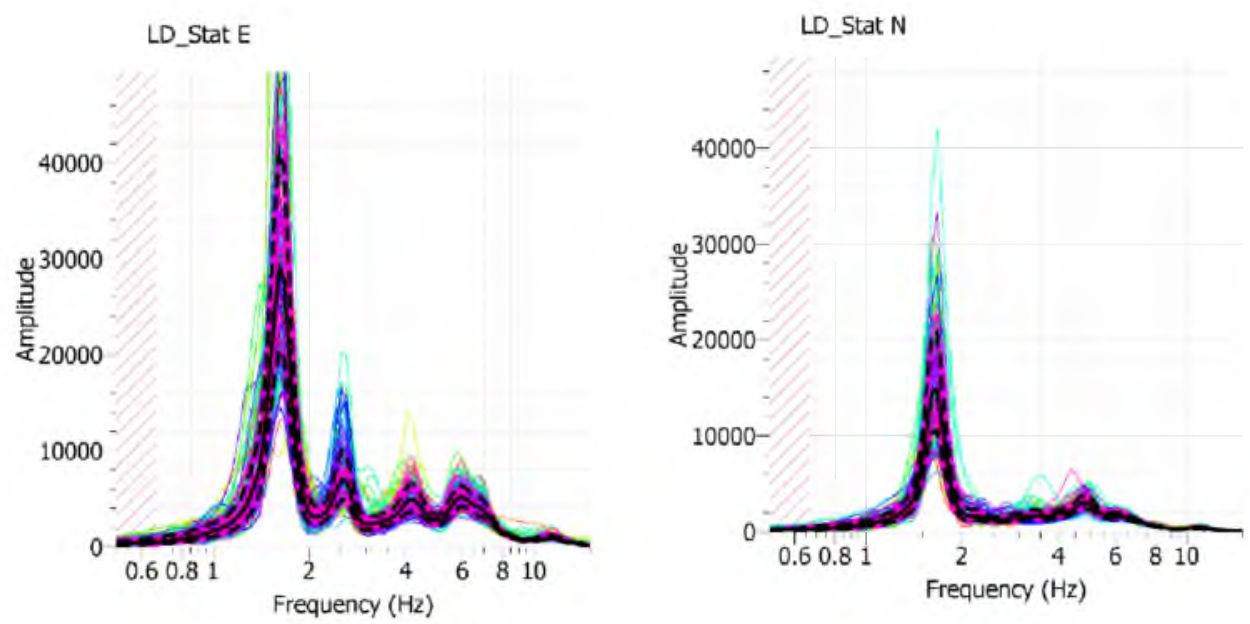

Gambar 3. Hasil FFT Mikrotremor pada Lantai 2
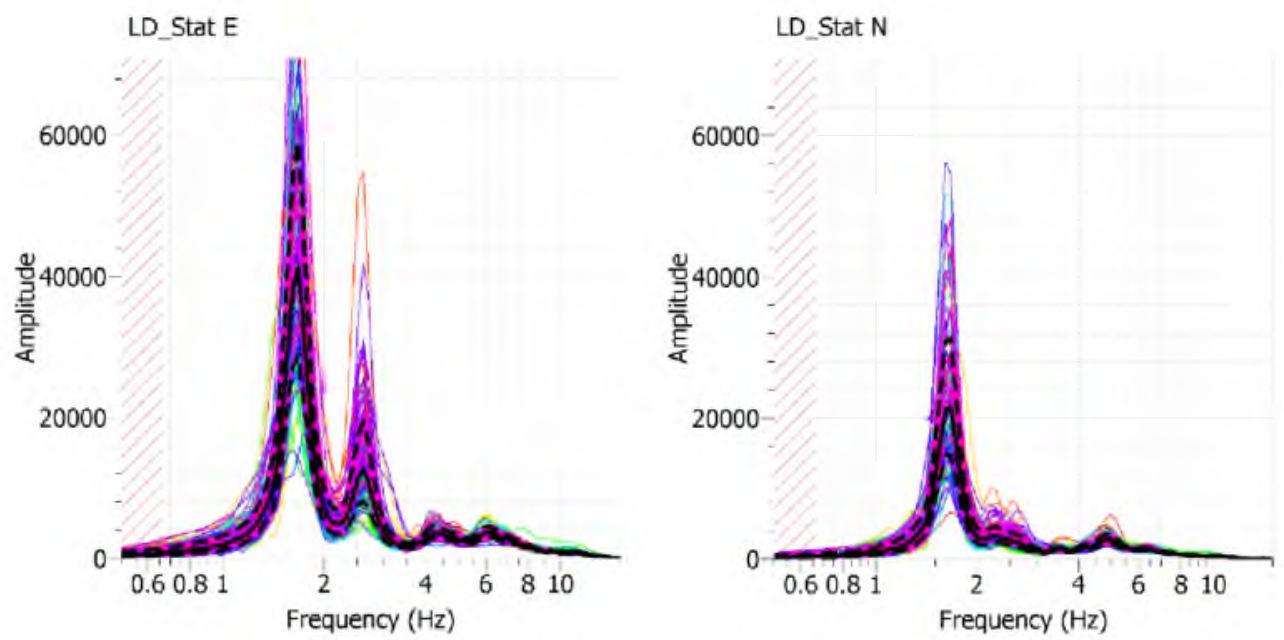

Gambar 4. Hasil FFT Mikrotremor pada Lantai 3 

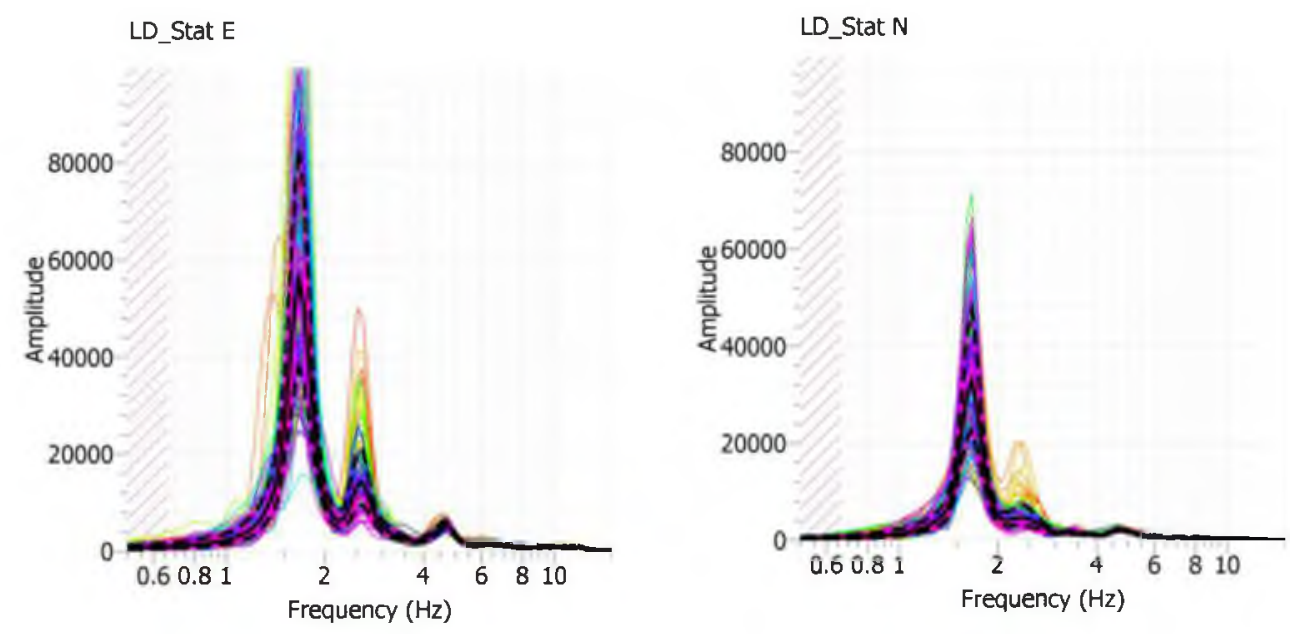

Gambar 5. Hasil FFT Mikrotremor pada Lantai 4
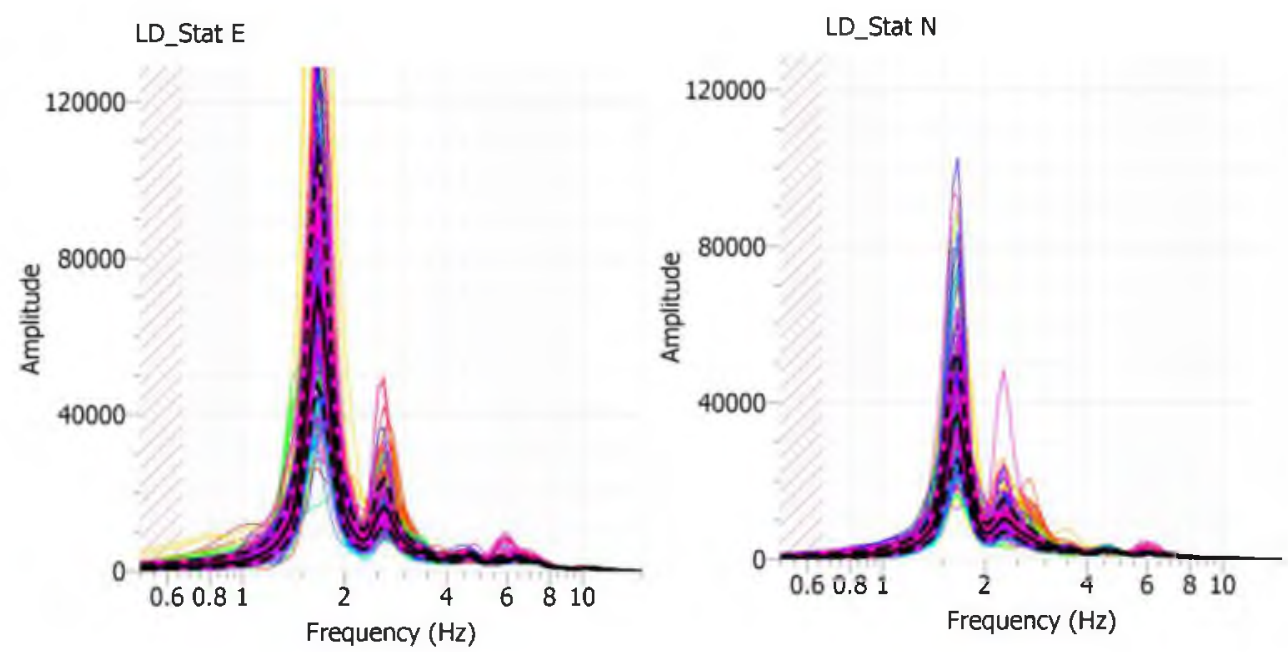

Gambar 6. Hasil FFT Mikrotremor pada Lantai 5

Melalui hasil perhitungan berdasarkan persamaan (1) dan (2) maka didapatkan nilai resonansi dan kerentanan gedung rektorat STTNAS sebagai berikut:

Tabel 2. Hasil Analisis Mikrotremor Arah NS

\begin{tabular}{|c|c|c|c|l|r|}
\hline Lantai & $\begin{array}{c}\text { Frekuensi } \\
(\mathrm{Hz})\end{array}$ & Amplitudo & Resonansi & $\begin{array}{c}\text { Tingkat } \\
\text { Resonansi }\end{array}$ & Kerentanan \\
\hline 1 & 1,61 & 2052,227055 & 31,00081 & rendah & 53533,1873 \\
\hline 2 & 1,64 & 6425,576338 & 33,44182 & rendah & 76197,01798 \\
\hline 3 & 1,63 & 8895,780774 & 32,62815 & rendah & 67917,16705 \\
\hline 4 & 1,66 & 14663,81035 & 35,06916 & rendah & 82526,5357 \\
\hline 5 & 1,66 & 16639,42584 & 35,06916 & rendah & 75238,2108 \\
\hline
\end{tabular}


Tabel 3. Hasil Analisis Mikrotremor Arah EW

\begin{tabular}{|c|c|c|c|l|l|}
\hline Lantai & $\begin{array}{c}\text { Frekuensi } \\
(\mathrm{Hz})\end{array}$ & Amplitudo & Resonansi & $\begin{array}{c}\text { Tingkat } \\
\text { Resonansi }\end{array}$ & Kerentanan \\
\hline 1 & 1,61 & 3974,275772 & 31,00081 & rendah & 103670,6191 \\
\hline 2 & 1,62 & 11732,82297 & 31,81448 & rendah & 142589,0162 \\
\hline 3 & 1,66 & 18248,36886 & 35,06916 & rendah & 134331,7196 \\
\hline 4 & 1,66 & 28083,31448 & 35,06916 & rendah & 158050,2339 \\
\hline 5 & 1,67 & 30788,5298 & 35,88283 & rendah & 137553,7098 \\
\hline
\end{tabular}

Berdasarkan hasil analisis dapat dilihat mengenai grafik hubungan kerentanan gempa pada tiap lantai yang dapat dilihat pada Error! Reference source not found., dan grafik hubungan amplitudo spektrum tiap lantai yang dapat dilihat pada Error! Reference source not found.

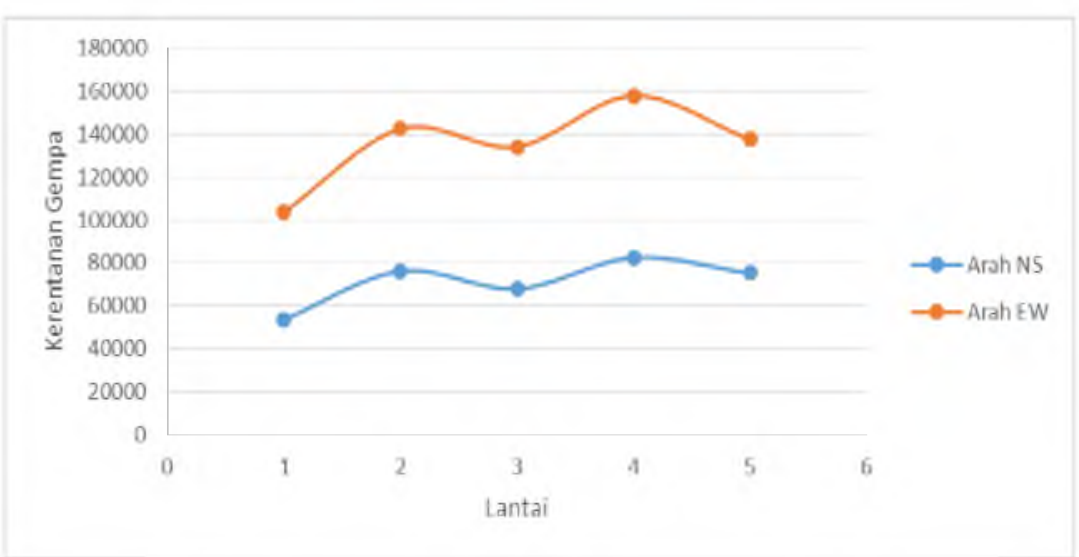

Gambar 7. Grafik Kerentanan Gempa Tiap Lantai

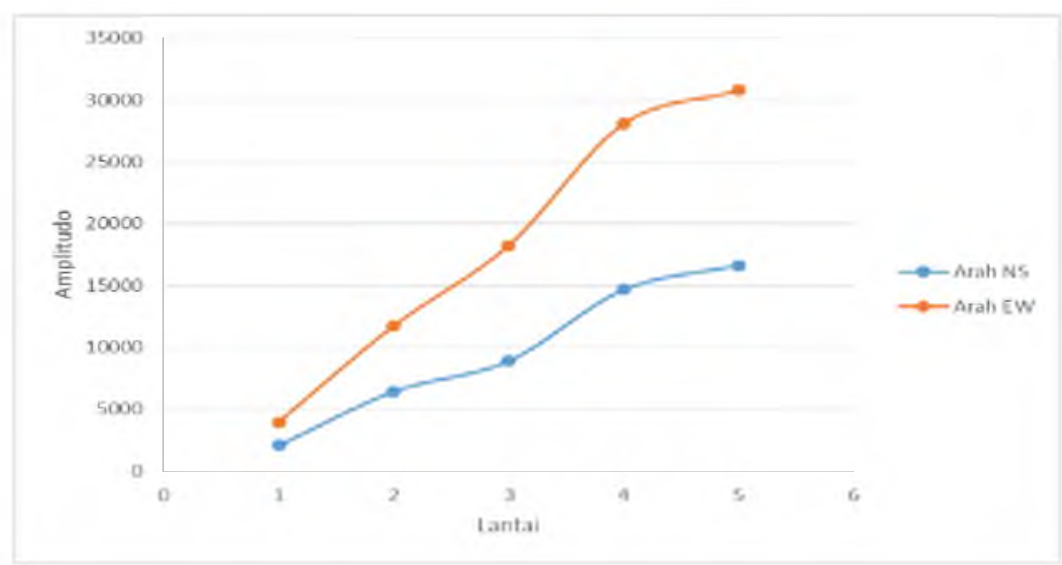

Gambar 8. Grafik Amplitudo Spektrum Pada Tiap Lantai

Berdasarkan Tabel 2 dan

Tabel 3 spektrum pada arah NS (Utara Selatan) dan EW (Barat Timur) menunjukkan bahwa nilai frekuensi natural tiap gedung identik atau hampir sama. Dibandingkan dengan standar SNI 2002 maka nilai frekuensi natural gedung Rektorat STTNAS masih memenhui standar SNI karena lebih dari 1,11 Hz. Selain itu, nilai amplitudo spektrum tiap lantai baik 
arah NS maupun EW semakin ke atas semakin besar nilai amplitudo, hal ini disebabkan tinggi gedung, semakin tinggi gedung nilai amplitudo semakin besar.

Berdasarkan Gambar 7 nilai kerentanan gempa tertinggi pada lantai 4 gedung rektorat STTNAS. Hal tersebut dikarenakan lantai 4 menopang beban lantai 5 dan atap, selain itu lantai 4 juga banyak terdapat sekat-sekat ruang jurusan dan dosen. Lantai 5 bernilai lebih rendah daripada lantai 4 karena kondisi ruangan yang sedikit sekat dan hanya menopang atap walupun lantai tertinggi yang memiliki amplitudo spektrum terbesar.

\section{Kesimpulan}

Hasil Fekuensi natural rata-rata gedung rektorat STTNAS pada komponen barat-timur adalah $1,64 \mathrm{~Hz}$ dan pada komponen utara-selatan adalah $1,644 \mathrm{~Hz}$ sehingga sudah sesuai dengan Standar Perencanaan Ketahanan Gempa Untuk Struktur Bangunan Gedung SNI (2002) yaitu lebih dari $1,11 \mathrm{~Hz}$.

Indeks Resonansi gedung rektorat STTNAS berkisar antara 31,00081-35,883\% sehingga temasuk dalam kategori rendah mengalami resonansi saat terjadi gempabumi. Indeks kerentanan gedung rektorat STTNAS berkisar antara 103670,6191-82526,5357dengan nilai tertinggi (paling rawan) terdapat pada lantai 4.

\section{Daftar Pustaka}

Aini, D., Utama, W. \& Bahri, A., 2012. Penaksiran Resonansi Tanah dan Bangunan Menggunakan Analisis Mikrotremor Wilayah Surabaya Jawa Timur. Jurnal Teknik POMITS, pp. 1-5.

Bahri, A., Utama, W., Aini, D. \& Lutfie, M., 2016. Valuation of Building strength against earthquake Vibrations using Microtremor Analysis (case study: the city of Surabaya). IOP Conf Series: Earth and Environmental Science.

Broptopuspito, K., Prasetya, T. \& Widigdo, F., 2006. Percepatan Getaran Tanah Maksimum Daerah Istimewa Yogyakarta 1943-2006. Jurnal Geofisika, Volume 1, pp. 19-22. Coburn, A. \& Spencer, R., 2002. Earthquake Protection, second Edition. Cambridge: John Wiley \& Sons.

Daryono, et al., 2009. Efek Tapak Lokal (Local Site effect) di Graben Bantul Berdasarkan Pengukuran Mikrotremor. International Conference Earth Science And Technology.

Elnashai, A., Kim, S., Yun, G. \& Sidarta, D., 2006. The Yogyakarta Earthquake of May 27, 2006, Illinois: Mid-America Eartquake Center.

Gosar, A., Roser, J., Sket, B. \& Zupancic, P., 2010. Microtremor Study of Site Effects and Soil Structure Resonance in the City of Ljubljana (Central Slovenia). B. Earthuake Engineering, Volume 8, pp. 571-592.

Herak, M., 2011. Overview of Recent Ambient Noise Measurement in Croatia in Free-Field and in Building. Geofizika, Volume 28.

Konno, K. \& Ohmachi, T., 1998. Ground Motion Characteristics Estimated From Spectral Ratio Between Horizontal To Vertical Components Of Microtremor. Bulletin of the Seismological of America, 88(1), pp. 228-241.

Okada, H., 2003. The Microtremor Survey Method (Geophysical Monograph Series Number 12), Amerika: Society of Exploration Geophysicists. 
Prabowo, U., Marjiyono \& Sismanto, 2016. Mapping the Fissure Potential Zones Based on Microtremor Measurement in Denpasar City, Bali. IOP Conf Series: Earth and Environmental Science, Volume 29.

Prakosa, P. et al., 2014. Earthquake Microzonation and Strength Building Evaluation at Gelora Bung Tomo Stadium Surabaya Using Microtremor Method. 7th International Conference on Physics and Its Applications 2014, pp. 14-19.

Sesame, 2004. Guidelines for the implementation of the $H / V$ spectral ratio technique on ambient vibration measurements and interpretation, European Commision-Research General Directorate: SESAME Europan Research Project.

Sudiyanto, A. D. T. et al., 2013. Analisis Mikrotremor Untuk Uji Kerentanan Bangunan Gedung Kuliah Pascasarjana FMIPA UGM, Yogyakarta: S2 Ilmu Fisika, UGM.

Sungkono, Warnana, D., Triwulan \& Utama, W., 2011. Evaluation of Buildings Strength From Mikrotremor Analyses. International Journal of Civil and Environmental Engineering, 11(5), pp. 93-99.

Tipler, P., 1991. Fisika Untuk Sains dan Teknik. Jakarta: Erlangga. 